\title{
Impact of sulfuric acid on carbonate dissolution in the upper-middle reaches of Wujiang River
}

\author{
Qibo Huang ${ }^{1, *}$, Xiaoqun Qin $^{1}$, Liankai Zhang ${ }^{1}$, and Pengyu Liu ${ }^{1}$ \\ ${ }^{1}$ Institute of Karst Geology, Chinese Academy of Geological Sciences, Guilin 541004, China
}

\begin{abstract}
Due to rapid population and economic growth in recent years, the Wujiang River has been heavily impacted by anthropogenic activities. Of particular concern is the increase in $\mathrm{SO}_{4}{ }^{2-}$ concentration of the river water from various anthropogenic sources. The results showed that the major cations of groundwater and surface water were $\mathrm{Ca}^{2+}$ and $\mathrm{Mg}^{2+}(>70 \%$ of the cation concentration), and the main anions were $\mathrm{HCO}_{3}{ }^{-}$and $\mathrm{SO}_{4}{ }^{2-}(>85 \%$ of the anion concentration). In groundwater, the contributions of carbonate dissolution to $\mathrm{Ca}^{2+}+\mathrm{Mg}^{2+}$ by sulfuric acid ranged from $20.6 \%$ to $92.9 \%$ (average $51.5 \%$ ); and to $\mathrm{HCO}_{3}{ }^{-}$from $11.5 \%$ to $86.7 \%$ (average $36.9 \%$ ). In the surface water, the contributions of carbonate dissolution to $\mathrm{Ca}^{2+}+\mathrm{Mg}^{2+}$ ranged from $56.1 \%$ to $94.6 \%$ (average $76.9 \%$ ); and to $\mathrm{HCO}_{3}{ }^{-}$from $39.0 \%$ to $89.7 \%$ (average $64.2 \%$ ). Our results demonstrate that besides carbonic acid, sulfuric acid also plays an important role on carbonate rock weathering, and influences the hydrochemistry of both groundwater and surface water in the Wujiang River drainage.
\end{abstract}

\section{Introduction}

Rivers play an important role in linking terrestrial and ocean chemical cycles by transporting solid and dissolved materials from land to the sea [1,2]. In particular, the riverine transport of carbon from the continents to the oceans plays an important role in the biogeochemical carbon cycle, which influences the global climate system [3,4]. The concentrations of dissolved inorganic carbon (DIC) and other major ions in river water are affected by both natural processes and anthropogenic impacts [5]. Identifying the source of major ions and DIC in river systems can help to identify the extent of the impact of human activity on the river water, as well as the effective management of it [6]. Such studies can help to minimize the damage from anthropogenic sources and help to protect the water resources $[7,8]$.

The Wujing River, the largest river in Guizhou Province, is a tributary of the Yangtze River and traverses the highest proportion of carbonate rocks. Due to the rapid population and economic growth in the region, the drainage basin is highly impacted by anthropogenic activities, such as urban/industrial waste water discharge, and agriculture. As a result, the area suffers from one of the highest rates of atmospheric acid deposition in southwestern China. Concentrations of both sulphate and nitrate have notably increased due to large amounts of

*Corresponding author: qbohuang@ karst.ac.cn 
chemical agricultural fertilizers and sewage effluents washed into the basin. Recent studies have looked into the sources of water chemistry and its controlling factors in the Wujing River. However, these studies were conducted on the basin scale and the hydrochemistry contributions of sulfuric acid to the river water have not yet been determined, which can help to better understand the influence of sulfuric acid on the river water chemistry.

\section{Materials and methods}

\subsection{Site description}

The upper reaches of Wujiang River, and nearby Sanca River, are located above Huawu town; the middle reaches are located between Huahu town and Sinan town, and the lower reaches are located between Sinan town and Huling town. The mean altitude of the upper reaches ranges from 1400 to $2000 \mathrm{~m}$ and is characterized by a main plateau and mountainous topography. The middle reaches range from 800 to $1400 \mathrm{~m}$, and are characterized by a hilly plateau basin. Downstream topography is characterized by hills and valleys with elevations $<800 \mathrm{~m}$. The ecological environment is prone to erosion and water loss as the topography is predominantly mountainous and the soil layer is thin. Wujiang River catchments are abundant in mineral resources, such as coal, bauxite, phosphate and rocks. However, the mineral resources are heavily exploited, resulting in large-scale pollution. According to previous measurements, the amount of the industrial wastewater released to the Wujiang River in 2002 was equivalent to 121 million tons; 34 million tons of which was released upstream of Liupanshui and Bijie prefectures; 84 million tons was released to the middle reaches of Guiyang, Anshun, and Qiannan prefectures and several counties of Bijie prefecture; and 4 million tons were released to the lower reaches of Zunyi region and several counties of Tongren prefecture. Over the last few decades. Guizhou Province has suffered one of the highest rates of atmospheric acid deposition in the region, attributed to high sulfur contamination from coal combustion.

\subsection{Samples and analyses}

Twenty-four surface water samples and twenty-six groundwater samples were collected in the middle of October 2013, from the upper-middle reaches of the Wujiang River. The locations of water samples are indicated in Fig. 1. 


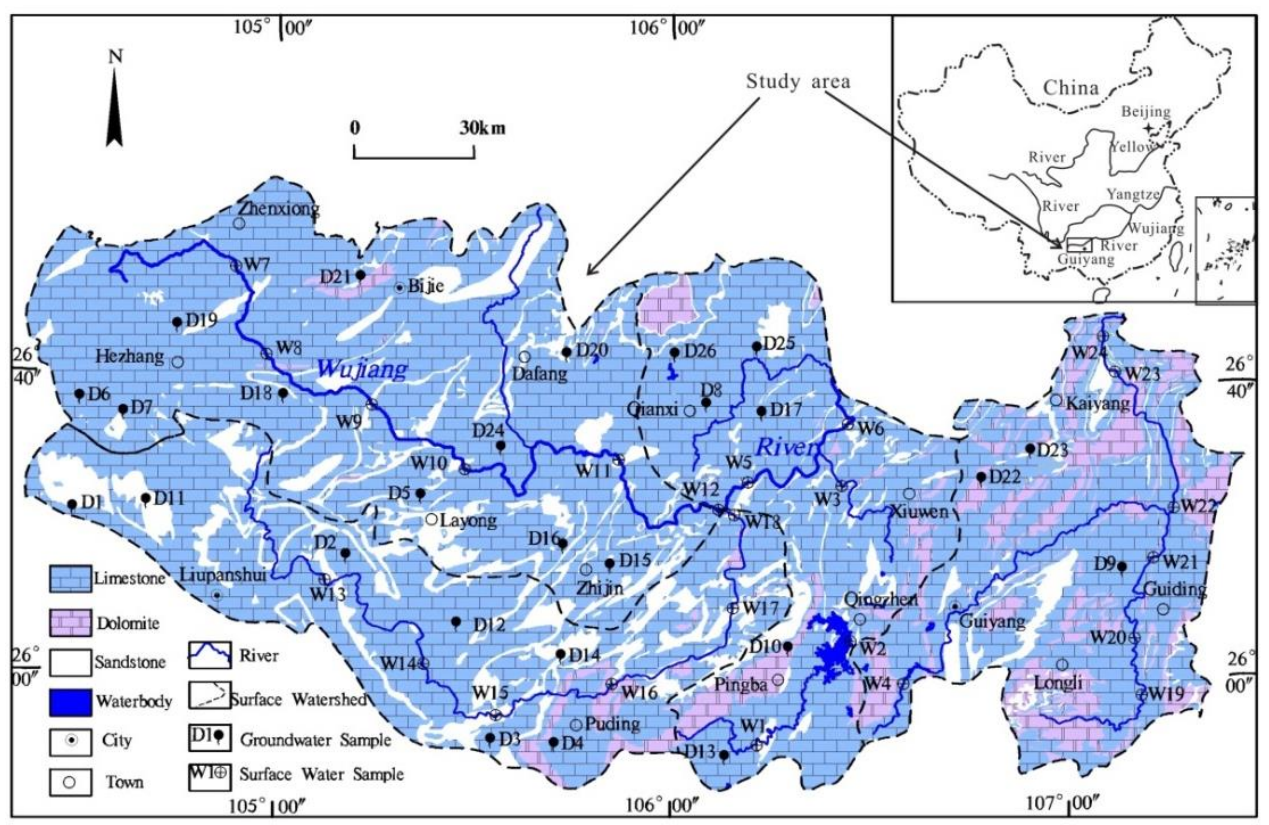

Fig. 1. Hydrogeology map of the drainage basin and sampling position.

\section{Results and Discussion}

\subsection{Chemical characteristics}

The $\mathrm{HCO}_{3}{ }^{-}$and $\mathrm{SO}_{4}{ }^{2-}$ are the dominant anions while $\mathrm{Ca}^{2+}$ and $\mathrm{Mg}^{2+}$ are the dominant cations in the upper-middle reaches of the Wujiang River. $\mathrm{HCO}_{3}{ }^{-}$and $\mathrm{SO}_{4}{ }^{2-}$ together accounted for more than $85 \%$ of the total anions and $\mathrm{Ca}^{2+}$ and $\mathrm{Mg}^{2+}$ accounted for $69 \%-98 \%$ of the total cations. The concentration of $\mathrm{HCO}_{3}{ }^{-}$in groundwater and surface water ranged from $2.03 \mathrm{mmol} / \mathrm{L}$ to 5.14 $\mathrm{mmol} / \mathrm{L}$ (mean $3.04 \mathrm{mmol} / \mathrm{L}$ ), and the concentration of $\mathrm{SO}_{4}{ }^{2-}$ ranged from $0.10 \mathrm{mmol} / \mathrm{L}$ to 1.39 $\mathrm{mmol} / \mathrm{L}$ (mean $0.71 \mathrm{mmol} / \mathrm{L}$ ). $\mathrm{Ca}^{2+}$ concentrations in water samples varied from $1.20 \mathrm{mmol} / \mathrm{L}$ to $2.82 \mathrm{mmol} / \mathrm{L}$ (mean $1.74 \mathrm{mmol} / \mathrm{L}$ ) and $\mathrm{Mg}^{2+}$ concentrations varied from $0.17 \mathrm{mmol} / \mathrm{L}$ to 1.31 $\mathrm{mmol} / \mathrm{L}$ (mean $0.51 \mathrm{mmol} / \mathrm{L}$ ). The piper diagram demonstrates that most samples for both groundwater and surface water plotted close to both the $\mathrm{Ca}^{2+}$ and $\mathrm{HCO}_{3}{ }^{-}$apexes (Fig.2) and thus, most samples were hydrochemically characterized as $\mathrm{Ca}-\mathrm{HCO}_{3}$ type. A small proportion of samples were characterized as $\mathrm{HCO}_{3} \cdot \mathrm{SO}_{4}$ - $\mathrm{Ca}$ type, indicating some contamination of $\mathrm{SO}_{4}{ }^{2-}$ in the river water, likely from various anthropogenic sources (industrial sewage / dissolution of soluble sulfate and sulfide minerals / atmospheric deposition. 


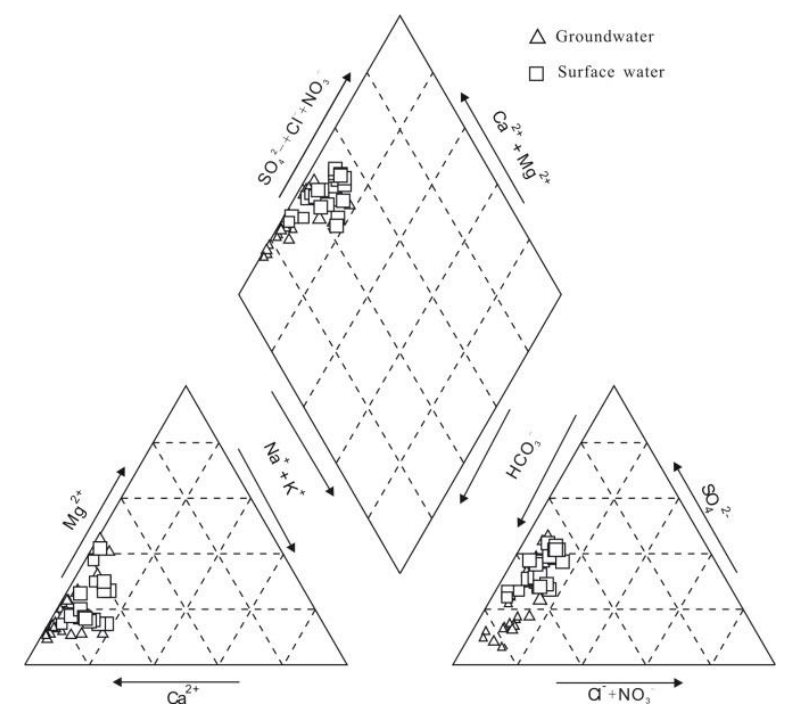

Fig. 2. Piper trilinear diagram of surface water and groundwater sample.

\subsection{Carbonate dissolution by carbonic acid versus sulfuric acid}

In this paper, we assume that except for carbonic acid and sulfuric acid, no other acid is involved in the dissolution of carbonate rock. So we assumed that $\mathrm{k}_{1} \mathrm{mmol} / \mathrm{L}$ carbonic acid and $\mathrm{k}_{2} \mathrm{mmol} / \mathrm{L}$ sulfuric acid would take part in the calculations for carbonate dissolution. Carbonate dissolution by both sulfuric and carbonic acids can therefore be described by the following equation:

$$
\begin{aligned}
& \left(k_{1}+2 k_{2}\right)\left(\mathrm{Ca}_{(1-x)} \mathrm{Mg}_{x}\right) \mathrm{CO}_{3}+k_{1} \mathrm{CO}_{2}+k_{1} \mathrm{H}_{2} \mathrm{O}+k_{2} \mathrm{H}_{2} \mathrm{SO}_{4}=\left(k_{1}+2 k_{2}\right)(1-x) \mathrm{Ca}^{2+}+\left(k_{1}+2 k_{2}\right) x \mathrm{Mg}^{2+}+ \\
& k_{2} \mathrm{SO}_{4}{ }^{2-}+2\left(k_{1}+k_{2}\right) \mathrm{HCO}_{3}{ }^{-}
\end{aligned}
$$

The concentration of $\mathrm{Ca}^{2+}$ and $\mathrm{Mg}^{2+}$ from atmospheric inputs were $0.15 \mathrm{mmol} \cdot \mathrm{L}^{-1}$, and the $\mathrm{HCO}_{3}{ }^{-}$concentration was generally very low. We can therefore assume that the concentrations of $\mathrm{HCO}_{3}{ }^{-}$are mainly derived from carbonate dissolution. The concentration of $\mathrm{Ca}^{2+}+\mathrm{Mg}^{2+}$ and $\mathrm{HCO}_{3}{ }^{-}$from carbonate dissolution can be expressed by the following equations:

$$
\begin{gathered}
{\left[\mathrm{Ca}^{2+}+\mathrm{Mg}^{2+}\right]_{\text {carbonate dissolution }}=\left[\mathrm{Ca}^{2+}+\mathrm{Mg}^{2+}\right]_{\text {sample- }}\left[\mathrm{Ca}^{2+}+\mathrm{Mg}^{2+}\right]_{\text {atmosphere }}} \\
{\left[\mathrm{Ca}^{2+}+\mathrm{Mg}^{2+}\right]_{\text {carbonate dissolution }}=k_{1}+2 k_{2}} \\
{\left[\mathrm{HCO}_{3}^{-}\right]_{\text {carbonate dissolution }}=2\left(k_{1}+k_{2}\right)}
\end{gathered}
$$

According to Eqs. 2, 3 and 4, the amount of carbonate dissolution by carbonic acid $\left(\mathrm{k}_{1}\right)$ and by sulfuric acid $\left(\mathrm{k}_{2}\right)$ can be calculated as follows:

$$
k_{l}=\left[\mathrm{HCO}_{3}{ }^{-}\right] \text {carbonate dissolution }-\left[\mathrm{Ca}^{2+}+\mathrm{Mg}^{2+}\right] \text { carbonate dissolution }
$$

The contributions of carbonate dissolution by carbonic acid and sulfuric acid to $\mathrm{Ca}^{2+}+\mathrm{Mg}^{2+}$ and $\mathrm{HCO}_{3}{ }^{-}$in groundwater, can be calculated by the following equations: 


$$
k_{2}=\left[\mathrm{Ca}^{2+}+\mathrm{Mg}^{2+}\right] \text { carbonate dissolution }-1 / 2\left[\mathrm{HCO}_{3}^{-}\right] \text {carbonate dissolution }
$$

The contributions of carbonate dissolution to $\mathrm{Ca}^{2+}+\mathrm{Mg}^{2+}$ and $\mathrm{HCO}_{3}{ }^{-}$by sulfuric acid in groundwater varied from $20.6 \%$ to $92.9 \%$ (average $51.5 \%$ ), and from $11.5 \%$ to $86.7 \%$ (average $36.9 \%$ ), respectively. In surface waters, the contributions of carbonate dissolution to $\mathrm{Ca}^{2+}+\mathrm{Mg}^{2+}$ and $\mathrm{HCO}_{3}{ }^{-}$by sulfuric acids in surface water ranged from $56.1 \%$ to $94.6 \%$ (average $76.9 \%$ ), and $39.0 \%$ to $89.7 \%$ (average $64.2 \%$ ), respectively.

\section{Conclusions}

The chemical composition of groundwater and surface water in the upper -middle reaches of Wujiang River were characterized by a dominance of $\mathrm{Ca}^{2+}, \mathrm{Mg}^{2+}, \mathrm{HCO}_{3}{ }^{-}$and $\mathrm{SO}_{4}{ }^{2-} . \mathrm{HCO}_{3}{ }^{-}$and $\mathrm{SO}_{4}{ }^{2-}$ together accounted for more than $85 \%$ of the total anions. $\mathrm{Ca}^{2+}$ and $\mathrm{Mg}^{2+}$ accounted for $69 \%-98 \%$ of the total cations. Hydrochemically, most samples were characterized by $\mathrm{Ca}-\mathrm{HCO}_{3}$ type, while only a small number of samples were characterized by $\mathrm{HCO}_{3} \cdot \mathrm{SO}_{4}-\mathrm{Ca}$, reflecting the influence of $\mathrm{SO}_{4}{ }^{2-}$ from human activities.

Our results demonstrate that sulfuric acid significantly affects the hydrochemistry of both groundwater and surface water in the study area. The contributions of carbonate dissolution to $\mathrm{Ca}^{2+}+\mathrm{Mg}^{2+}$ and $\mathrm{HCO}_{3}{ }^{-}$by sulphuric acid in groundwater ranged from $20.59 \%$ to $92.87 \%$ (average $51.50 \%$ ), and from $11.47 \%$ to $86.69 \%$ (average $36.90 \%$ ). In comparison, the contributions of carbonate dissolution to $\mathrm{Ca}^{2+}+\mathrm{Mg}^{2+}$ and $\mathrm{HCO}_{3}{ }^{-}$by sulphuric acid in surface water ranged from $56.14 \%$ to $94.55 \%$ (average $76.89 \%$ ), and $39.02 \%$ to $89.66 \%$ (average $64.24 \%$ ), respectively. The results demonstrate that besides carbonic acid, sulfuric acid from anthropogenic contamination, plays an important role on carbonate rock weathering and influences hydrochemistry in the river water.

Supported by the National Natural Science Foundation of China (NSFC) (41571203) and the Geological Survey Project (12120113005200).

\section{References}

1. A. Galy, C. France-Lanord. Chem. Geol., 159, 31-60 (1999)

2. GL. Han, CQ. Liu. Chem. Geol., 204, 1-21 (2004)

3. M. Meybeck, C. Vörösmarty. Glob. Change. Newsl., 37, 18-19 (1999)

4. J.Gaillardet, B. Dupré. P. Louvat, CJ. Allégre. Chem. Geol,. 159,3-30 (1999)

5. PA. Raymond, NH. Oh, RE. Turner, W. Broussard. Nature., 451,449-452 (2008)

6. A. Das, S. Krishnaswami, SK. Bhattacharya. Earth. Planet. Sci. Lett., 236,419-29 (2005)

7. K.S. Lee, JS. Ryu, KH. Ahn, HW. Chang, D. Lee. Hydrol. Process., 21:500 (2007)

8. R.T. Barnes, P.A. Raymond. Chem. Geol., 266, 318-327 (2009) 